\section{Social justice and research using human biologicall material: A right to respond}

To the Editor: This communication refers to an article by Jordaan ${ }^{[1]}$ titled 'Social justice and research using human biological material: A response to Mahomed, Nöthling-Slabbert and Pepper', which appeared in the July 2016 SAMJ.

The original article ${ }^{[2]}$ to which Jordaan refers and has responded was first published in the South African Journal of Bioethics and Law in 2013 and is titled 'The legal position on the classification of human tissue in South Africa: Can tissues be owned?'

We note with great concern that Jordaan's response was published in the $S A M J$, 3 years after the publication of our original article, which he refers to as a 'recent' article. We would like to correct this misinformation, as our original article is in fact not recent. Because of the lapse in time, and the fact that Jordaan's response was published in a different journal, readers of the $S A M J$ may not have a comprehensive understanding of the content of our original article. Furthermore, as authors of that article we were not provided, as one would expect in terms of editorial practice and ethics, with an opportunity to respond to Jordaan, or even notified that his article was going to appear in your journal.

In his response, Jordaan has clearly misinterpreted the issues we raise regarding ownership of human tissues, a matter that has been debated extensively in the academic sphere for some time. Jordaan has chosen, very selectively and most likely deliberately, to pick on certain aspects of our original article and question the credibility of our opinions, to which we are fully entitled. A critique provided in a staccato fashion, without considering the aims and arguments purported in our original article as a whole, can only be flawed. Furthermore, the allegations and conclusions that Jordaan has reached in his response are unjustified and do not function to further academic debate on the ethical and legal issues that we considered. There are, however, certain aspects that Jordaan has pointed out in his response that we do appreciate in the spirit of academic discourse. His overall intention was to highlight our alleged weak and unconvincing arguments. However, it is our opinion that your omission, as Editor, to provide us with the opportunity to respond to Jordaan's article in the same issue is not conducive to healthy academic discussion and debate.

We are quite sure that the intention of an established journal like the $S A M J$ is to uphold the principles of editorial ethics and academic professionalism. As the original authors of the article to which Jordaan has responded, we hereby wish to inform you that we reserve our right to reply. A full response will be submitted to your journal in due course.

\section{S Mahomed}

Department of Jurisprudence, College of Law, University of South Africa mahoms1@unisa.ac.za

\section{Nöthling Slabbert}

College of Law, University of South Africa

\section{S Pepper}

Institute for Cellular and Molecular Medicine, South African Medical Research Council Extramural Unit for Stem Cell Research and Therapy, and Department of Immunology, Faculty of Health Sciences, University of Pretoria, South Africa

1. Jordaan DW. Social justice and research using human biological material: A response to Mahomed, Nöthling-Slabbert and Pepper. S Afr Med J 2016;106(7):678-680. DOI:10.7196/SAMJ.2016.v106i7.10552 2. Mahomed S, Nöthling-Slabbert M, Pepper MS. The legal position on the classification of human tissue in South Africa: Can tissues be owned? S Afr J Bioethics Law 2013;6(1):16-20. DOI:10.7196/SAJBL.258

S Afr Med J 2016;106(9):841. DOI:10.7196/SAMJ.2016.v106i9.11379 